\title{
Mammals of a restinga forest in Mataraca, Paraíba, northeastern Brazil, and its affinities to restinga areas in Brazil
}

\author{
Bruno Augusto Torres Parahyba Campos ${ }^{1 *}$, Anderson Feijo ${ }^{2,3}$, Pamella Gusmão de Goés Brennand ${ }^{3}$ \\ Alexandre Reis Percequillo ${ }^{4,5}$ \\ ${ }^{1}$ Universidade Estadual do Maranhão, Centro de Estudos Superiores de Caxias, Laboratório de Genética e Biologia \\ Molecular, Praça Duque de Caxias, S/N. Morro do Alecrim, 65604-380, Caxias, MA, Brazil \\ ${ }^{2}$ Chinese Academy of Sciences, Key Laboratory of Zoological Systematics and Evolution, Institute of Zoology, \\ Beichen West Road, 100101, Chaoyang District, Beijing, China \\ ${ }^{3}$ Universidade Federal da Paraíba, Departamento de Sistemática e Ecologia, Centro de Ciências Exatas e da \\ Natureza, Laboratório de Mamíferos, Campus Universitário, 58059-900, João Pessoa, PB, Brazil \\ ${ }^{4}$ Universidade de São Paulo, Escola Superior de Agricultura “Luiz de Queiroz”, Departamento de Ciências \\ Biológicas, Av. Pádua Dias, 11 C.P. 9, 13423-353, Piracicaba, SP, Brazil \\ ${ }^{5}$ The Natural History Museum, Department of Life Sciences, Cromwell Road, London SW7 5BD,UK \\ *Corresponding author: Bruno Augusto Torres Parahyba Campos, e-mail: atpcampos@gmail.com
}

CAMPOS, B. A. T. P., FEIJÓ, A., BRENNAND, P. G. G., PERCEQUILLO, A. R. Mammals of a restinga forest in Mataraca, Paraíba, northeastern Brazil, and its affinities to restinga areas in Brazil. Biota Neotropica. 18(1): e20170392. http://dx.doi.org/10.1590/1676-0611-BN-2017-0392

\begin{abstract}
The Restinga forests are plant formations associated to the Atlantic Forest which still have not been much studied in terms of their mastofauna. The objective of the present work was to list for the first time the mammal species found in a Restinga on northeastern Brazil and show the similarities on species composition to other areas of the same environment and of Atlantic Forest. Our records were based on several complementary approaches: field survey, interviews, and museum collections. Subsequently, we performed similarity analysis between Restinga areas along Brazil and Atlantic Forest areas. We found a total of 30 species of mammals distributed in 28 genera, 16 families and 7 orders for Restinga of Mataraca. Species richness was similar to other Restinga areas and similarity analyzes pointed out that Restingas are more closely related to adjacent Atlantic Forest areas than to other Restingas in the country. This suggests that Restingas do not exhibit an autochthone fauna, but rather a faunal subsample of neighbor Atlantic Forest. Therefore, conservations policies for the Restinga habitat depends not only on actions focused on this habitat, but on initiatives that encompass nearby Atlantic Forest remnants, allowing the connectivity between these habitats.
\end{abstract}

Keywords: Atlantic Forest, Mammals, Restinga, Mataraca, Paraiba.

\section{Mamíferos de uma floresta de Restinga em Mataraca, Paraíba, Nordeste do Brasil e suas afinidades com áreas de Restinga no Brasil}

Resumo: As restingas são formações vegetais associadas à Floresta Atlântica e ainda pouco exploradas em relação a sua mastofauna. O objetivo desse trabalho foi listar pela primeira vez as espécies de mamíferos presentes em uma restinga no nordeste do Brasil e mostrar sua similaridade com outras áreas do mesmo ambiente e de Mata Atlântica. A listagem foi baseada em diversas abordagens complementares: coletas, entrevistas, material em coleção. Posteriormente realizamos análises de similaridade entre áreas de restinga ao longo do Brasil e áreas de Mata Atlântica. Encontramos um total de 30 espécies de mamíferos distribuídas em 28 gêneros, 16 famílias e sete ordens para restinga de Mataraca. A riqueza ficou próxima a de outras áreas de restinga e as análises de similaridade apontaram que as restingas são mais proximamente relacionadas com as áreas adjacentes de Floresta Atlântica do que com as outras restingas no país. Isso sugere que as Restingas não exibem uma fauna autóctone ou endêmica, mas que sua fauna representa um subconjunto da fauna da Floresta Atlântica mais próxima. Dessa forma, estratégias para a conservação das Restingas não dependem apenas de ações nesse ambiente, mas de iniciativas que atinjam áreas de Mata Atlântica próximas, que garantam a conectividade entre estas.

Palavras-chave: Floresta Atlântica, Mamíferos, Restinga, Mataraca, Paraíba. 


\section{Introduction}

The Restinga forests of northeastern Brazil grow on the coastal sandy lowland areas that were formed from sand deposits in regions that were below sea level during the Quaternary period (Thomas \& Barbosa 2008). The Restinga forests form a vegetation complex typical of the coastal zone, very common along beaches, sandy cords and coastal surfaces, where the soil is sandy and poor in nutrients (Thomas \& Barbosa 2008). This vegetation, contiguous to the Atlantic Forest, constitutes a mosaic of phytophysiognomies, ranging from open grassland savannas to forests (Pereira 2001, Scarano 2002). This diversity of environments favors the presence of plant species with different ecological requirements, which could suggest the presence of a great biological diversity in these areas (Moreira \& Mendes 2010).

Restingas are under great anthropic pressure, mainly from habitat loss and fragmentation, due to real estate activities (Zamith \& Scarano 2006, Rocha et al. 2007) and industrial activities, leading to decline of populations of mammals (Fonseca et al. 1996). The composition of the mammal fauna in this coastal habitat is poorly known and the few studies are restricted to the southern (e.g. Fabián et al. 2010, Quintela et al. 2012) and southeastern Brazil (e.g. Cerqueira et al. 1990, Cerqueira 2000, Luz et al. 2009, 2011, Oprea et al. 2009, Nogueira et al. 2010, Pêssoa et al. 2010). The mammal fauna of Restinga has been considered as a subset of the fauna of the Atlantic Forest with no particular identity (Cerqueira et al. 1990, Cerqueira 2000), although three rodent species are endemic of these areas: Cerradomys goytaca, Ctenomys lami and Ctenomys flamarioni (Pêssoa et al. 2010, Tavares et al 2011, Lopes et al. 2010).

Until now, no consistent sampling effort, either short-term collecting or exhaustive inventory (Voss \& Emmons 1996), has documented the diversity of mammals in the Restingas of northeastern Brazil. Therefore, in this contribution we aim to provide the first survey of mammals of a Restinga area on northern Paraíba state on northeastern Brazil, based on short-term collecting and to compare the similarity on the species richness with other Restinga and Atlantic Forest areas.

\section{Material and Methods}

\section{Studied Area}

The present work was carried out in the Mataraca municipality, on the northern portion of the coast of the state of Paraíba (6 $\left.6^{\circ} 29^{\prime} \mathrm{S}, 34^{\circ} 56^{\prime} \mathrm{W}\right)$ (Figure 1), at the hydrographic basin of Guaju river, located mainly on coastal

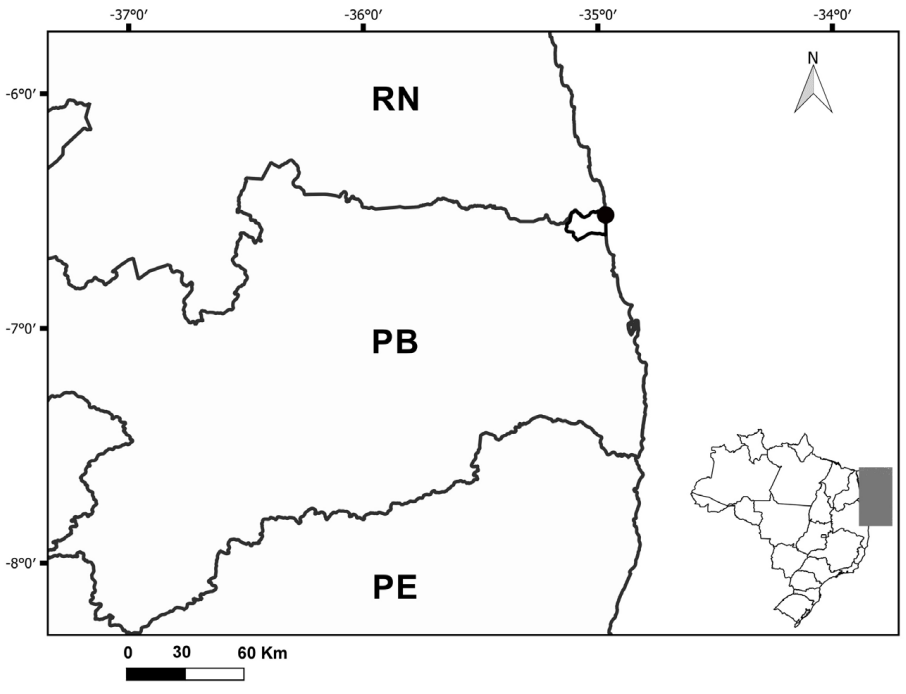

Figure 1. Sampling site on the municipality of Mataraca, Brazil. RN= Rio Grande do Norte state; $\mathrm{PB}=$ Paraíba state $\mathrm{PE}=$ Pernambuco state dunes (Figure 2). The geological constitution is essentially sedimentary, represented by sandy-clayey sediments of Neogeno-Quaternary age, belonging to the Barreiras Group and sandy sediments of recent age (Mabesone \& Castro 1975). The region's climate is of the Am type, following Köppen's classification, the wet season occurs from April to August and the average annual precipitation and temperature is $1.745 \mathrm{~mm}$ and $25.5^{\circ} \mathrm{C}$ respectively (Cunha et al. 2003).

The area belonged to Lyondell Chemical Company, which mined the studied area for 33 years. The company carried out a habitat restoration project to compensate the damage of mining activities, and several patches of different ages of restoration exist in the area, as well as fully protected Restinga areas. The field work occurred in these protected areas of Open Restinga and Restinga Forest habitats (Figure 2) to avoid the impact of restoration on our survey. The first habitat is located in the regions closest to the sea and with sandy soils; the vegetation is mainly shrub with shallow litter. The most abundant plant species are: Anacardium occidentale, Tocoyena selloana, and Mimosa caesalpiniaefolea. The Restinga forests are composed by emergent trees of up to $10 \mathrm{~m}$ in height, and abundance of lianas. The canopy is closed, the understory in moderately open, and the forest floor is covered by dense litter and decaying trunks. The most abundant plant species are: Sacoglottis mattogrossensis, Chamaecrista ensiformis, Protium heptaphyllum (Duré 2013).

\section{Data collection}

The species list was established through three methodologies: field inventory, interviews and study of specimens at the Mammal Collection of the Universidade Federal da Paraíba (UFPB). We follow the nomenclature proposed by Wilson \& Reeder (2005) for orders Carnivora and Primates, Gardner (2008) for Didelphimorphia, Pilosa, Cingulata and Chiroptera, Feijó \& Langguth (2013) for the genus Dasyprocta, Gurgel-Filho et al. (2015) for the genus Didelphis and Patton et al. (2015) for the order Rodentia.

\section{Field Inventory}

The field inventory was carried out between October 2005 and July 2008 with two campaigns per year (dry and rainy seasons), where small non-volant mammals were sampled through transects with conventional (live traps: Sherman's and Tomahawk's) and pitfall traps (see Voss \& Emmons, 1996). Conventional traps were placed on and above the ground (up to a height of $2 \mathrm{~m}$ ) and baited with bananas, peanut and oatmeal mixed. The material collected was deposited at the Mammal collection of the Universidade Federal da Paraíba (UFPB). All specimens were collected and prepared according to protocols established and approved by the "Animal Care and Use Committee" of the American Society of Mammalogists (Sikes et al. 2016).

Medium and large mammals were sampled through daily censuses on previous known transects $(10 \mathrm{~km})$ in order to record direct and indirect vestiges. Transects were surveyed by car at low speed and walked twice a day (whenever it is possible, early morning and evening), throughout the campaigns. Transects made by car corresponded to access ways between small mammals surveyed areas. The routes carried out by foot correspond to trails in the vicinities of the trapping points. This methodology was complementary and not standardized, thus we have no available information in effort and success for this approach.

\section{Interviews}

The interviews were conducted during field inventories with residents and workers of the mining company, that known the area and its fauna in detail. We asked them about medium and large mammals, using colored 

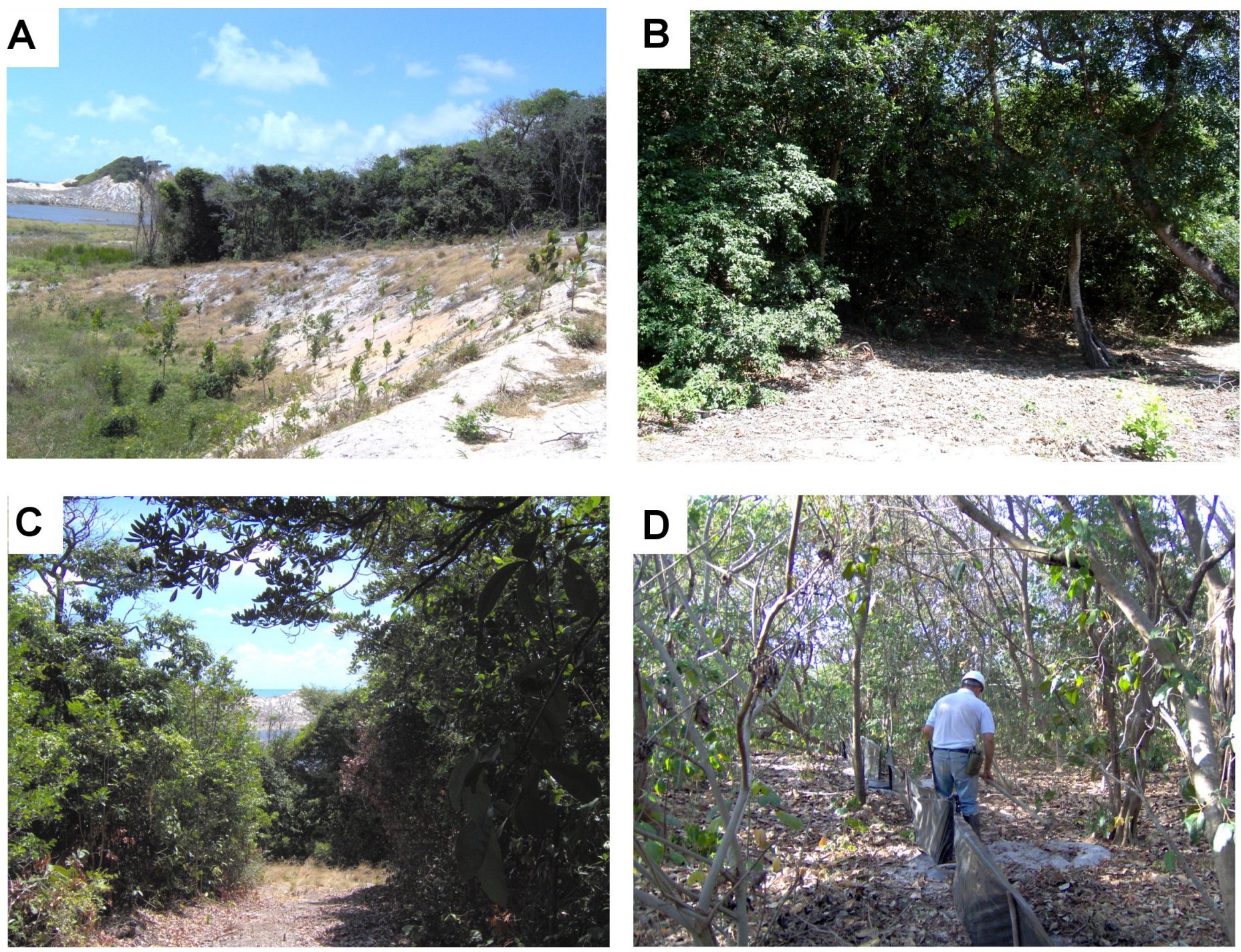

Figure 2. Restinga landscape in the sand dunes in Mataraca, Paraíba. (A) Note the forest on the upper parts of the dunes, the grassy and bush habitats on the slopes and on the lower portions; the lagoon on the background is surrounded by grassland. (B) Detail of the border of a fragment of Restinga Forest. (C) Trail on the Restinga habitat, with sand dunes and the ocean in the background. (D) Detail of open forest Restinga habitat showing one pitfall trap line (Photos: Bruno Campos).

plates as templates from Linares (1998), Emmons \& Feer (1990) and Eisenberg \& Redford (1999), as suggested by Voss \& Emmons (1996).

\section{Mammal collection of UFPB}

Records for the small-volant mammals from Restinga of Mataraca were obtained at the UFPB collection. Additionally, we also included records of medium mammals, rodents and marsupials.

\section{Analyses}

We calculate the sampling effort (number of traps * sampling days) and the sampling success ([number of records / sampling effort] * 100) only for the live-trap sampling (conventional and pitfall); these data are also employed to obtain rarefaction curve. The diversity index (Jackknife 1 based on 1,000 runs) was calculated through EstimateS 9.0 (Colwell 2013).

Analyzes of similarities were performed using the PAST program (Hammer et al. 2009) through an array of localities * species and the dendograms were generated using the coefficient of Jaccard. Two levels of analyses were performed, one for all mammals and one for non- volant small mammals. These two approaches were used because the knowledge about Restinga mammals is mainly focused on small nonvolant mammals. We included in the analyses only areas of Restinga that had been inventoried with at least two methodological approaches (e.g., pitfall and livetraps, or trapping and museum database), and with a sampling effort greater than 500 traps per night for the small mammals (Table 1; Supplementary Material 1 for data matrix). In order to test similarity among ecosystems, close Atlantic Forest areas of the Restinga were included for comparisons (Table 1). Although the efforts are different, the similarity analysis will provide an initial picture of the similarities between the Restingas and adjacent Atlantic Forest areas and may respond whether the Restinga forest forms an independent unit or represent a subgroup of the Atlantic Forest.

\section{Results}

A total of 30 species, distributed in 28 genera, 16 families and seven orders were registered for the Restinga of Mataraca (Table 2). The total sampling effort was 3.758 traps-night for the conventional live 
Campos, B.A.T.P. et al.

Table 1. Mammal inventories in Restinga and neighboring Atlantic Forest areas in Brazil employed in the analyses of similarity, indicating the mammal groups included in the analyses.

\begin{tabular}{|c|c|c|c|}
\hline Localities & Vegetation & $\begin{array}{l}\text { Group of } \\
\text { Mammals }\end{array}$ & Reference \\
\hline Barra de Maricá, Maricá, Rio de Janeiro & Restinga & All & Cerqueira et al. 1990, Cerqueira 2010 \\
\hline REBIO Guaribas, Mamanguape, Paraíba & Atlantic Forest with savanna's patches & All & Feijó et al. 2016 \\
\hline Mata do Buraquinho, João Pessoa, Paraíba & Atlantic Forest & All & Percequillo et al. 2007 \\
\hline Parque Nacional Restinga de Jurubatiba, Rio de Janeiro & Restinga & All & Pêssoa et al. 2010 \\
\hline Parque Estadual Paulo César Vinha, Guarapari, Espirito Santo & Restinga & All & Moreira \& Mendes 2010 \\
\hline Reserva Biológica Poço das Antas, Rio de Janeiro & Atlantic Forest & All & Pêssoa et al. 2010 \\
\hline Sítio Santana, Quissamã, Rio de Janeiro & Restinga & Small non-volant & Pêssoa et al. 2010 \\
\hline Parque Natural Municipal Fazenda Atalaia, Macaé, Rio de Janeiro & Atlantic Forest & Small non-volant & Pêssoa et al. 2010 \\
\hline Cabiúnas, Macaé, Rio de Janeiro & Atlantic Forest & Small non-volant & Pêssoa et al. 2010 \\
\hline Mata da Estrada Velha, Rio Grande, Rio Grande do Sul & Restinga & Small non-volant & Quintela et al. 2012 \\
\hline Arroio Bolaxa, Rio Grande, Rio Grande do Sul & Restinga & Small non-volant & Quintela et al. 2012 \\
\hline
\end{tabular}

Table 2. Species of mammals recorded in Mataraca Restinga, Paraíba, and the sampling method. LT - live trap; CO- UFPB collection; IN -interview; VE- Vestiges; DO - Direct observation. *According to Gurgel-Filho et al. (2015).

\begin{tabular}{lc}
\hline \multicolumn{1}{c}{ Taxa } & Sampling metho \\
\hline ORDER DIDELPHIMORPHIA & \\
Didelphidae & CO \\
Caluromys philander (Linnaeus, 1758) & LT/VE/DO \\
*Didelphis marsupialis Linnaeus, 1758 & LT \\
Marmosa murina (Linnaeus, 1758) & LT/DO \\
Monodelphis domestica (Wagner, 1842) & LT \\
Gracilinanus agilis (Burmeister, 1854) & LT/DO \\
Marmosa demerarae (Thomas 1920) & \\
ORDER CINGULATA &
\end{tabular}

\section{ORDER CINGULATA}

Dasypodidae

Dasypus novemcinctus Linnaeus, 1758

Chlamyphoridae

Euphractus sexcinctus (Linnaeus, 1758)

ORDER PILOSA

Bradypodidae

Bradypus variegatus (Schinz, 1825)

Myrmecophagidae

Tamandua tetradactyla (Linnaeus, 1758)

Cyclopes didactylus (Linnaeus, 1758)

\section{ORDER CHIROPTERA}

Emballonuridae

Rhynchonycteris naso (Wied-Neuwied, 1820)

Phyllostomidae

Phyllostomus discolor (Wagner, 1843):

Glossophaga soricina (Pallas, 1766)

Carollia perspicillata (Linnaeus, 1758)

Artibeus planirostris (Spix, 1823)

Artibeus cinereus (Gervais, 1856)

Platyrrhinus lineatus (E. Geoffroy 1810)

ORDER PRIMATES

Cebidae

Callithrix jacchus (Linnaeus, 1758)

Cebus (Sapajus) flavius (Schreber, 1774)

Atelidae

Alouatta belzebul (Linnaeus 1766)

ORDER RODENTIA

Cricetidae

Oligoryzomys nigripes (Olfers, 1818)

Dasyproctidae

Dasyprocta iacki Feijó and Langguth, 2013

Erethizontidae

Coendou prehensilis (Linnaeus, 1758)

Echimyidae

Thrichomys laurentius (Thomas, 1904)

Phyllomys blainvilii (Jourdan, 1837)

ORDER CARNIVORA

Felidae

Leopardus sp.

IN

LT/VE/IN/CO/DO

IN

IN

IN

Canidae

Cerdocyon thous (Linnaeus, 1766)

Mustelidae

Lontra longicaudis (Olfers, 1818)

Procyonidae

Procyon cancrivorus (Cuvier, 1793)

$\mathrm{CO}$

$\mathrm{CO}$

$\mathrm{CO}$

$\mathrm{CO}$

$\mathrm{CO}$

$\mathrm{CO}$

$\mathrm{CO}$

$\mathrm{VE} / \mathrm{IN} / \mathrm{DO}$

$\mathrm{VE} / \mathrm{IN} / \mathrm{DO}$

VE/IN/DO

LT

VE/IN/DO

VE/IN/DO

LT

LT

$\mathrm{VE} / \mathrm{IN}$

$\mathrm{VE} / \mathrm{IN} / \mathrm{DO}$

IN

VE/IN

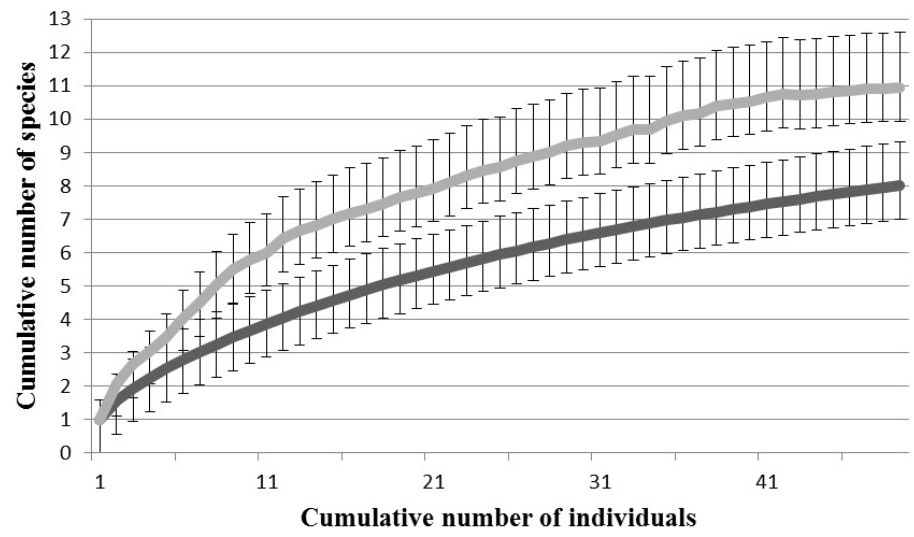

Figure 3. Curve of species accumulation for the non volant small mammals recorded in Restinga in Mataraca, Northeastern Brazil. Gray curve= jacknife 1; Dark curve $=$ observed data. The vertical bars correspond to standard deviation. trap and 3.090 traps-night for the pitfall. The small mammal sampling during field inventories resulted in the capture of 49 individuals classified in eight species of the orders Rodentia and Didelphimorphia, with 3 and 5 species, respectively. We also obtained 2 individuals of 1 species of the order Cingulata (Euphractus sexcinctus) during the surveys; the specimens were captured in pitfall traps.

The censuses resulted in the record of six species, being five through indirect evidence such as tracks, two through scats, and nine by direct observations (Table 2). Four other species were recorded exclusively through interviews: Dasypus novemcinctus, Bradypus variegatus, Tamandua tetradactyla and Cyclopes didactylus. The specimens of UFPB represent eight species, seven bats and the marsupial Caluromys philander (Table 2).

The capture success for small mammals with the conventional traps was $1.27 \%$ and $0.32 \%$ with the pitfall traps; considering both methods, we have a capture success rate of $0.71 \%$. The rarefaction curves show a small tendency to the increase of small mammal species (Figure 3). The Jackknife 1 suggests a higher richness of small mammal species in the area than we recorded with significant difference (observed $=8$, expected $=11$; Figure 3 ). The most abundant species was the white-eared opossum Didelphis marsupialis, followed by Monodelphis domestica representing $80 \%$ of total captures (Figure 4 ).

The analyses of similarity for all terrestrial mammal groups (Figure 5) showed that localities of Restinga (Mataraca) and Atlantic Forest (Reserva Biológica Guaribas and Mata do Buraquinho) from 
Northeastern Brazil are more similar among themselves, as the areas of Restinga and Atlantic Forest from Southeastern Brazil. Considering only the small non-volant mammals (Figure 6), our results recovered that localities of northeastern Brazil share faunal elements, regardless of the habitat, as areas from other regions (Southern and Southeastern); in this analyses, the Restinga of Rio Grande do Sul is more similar with the areas of northeastern Brazil than those with southeastern.

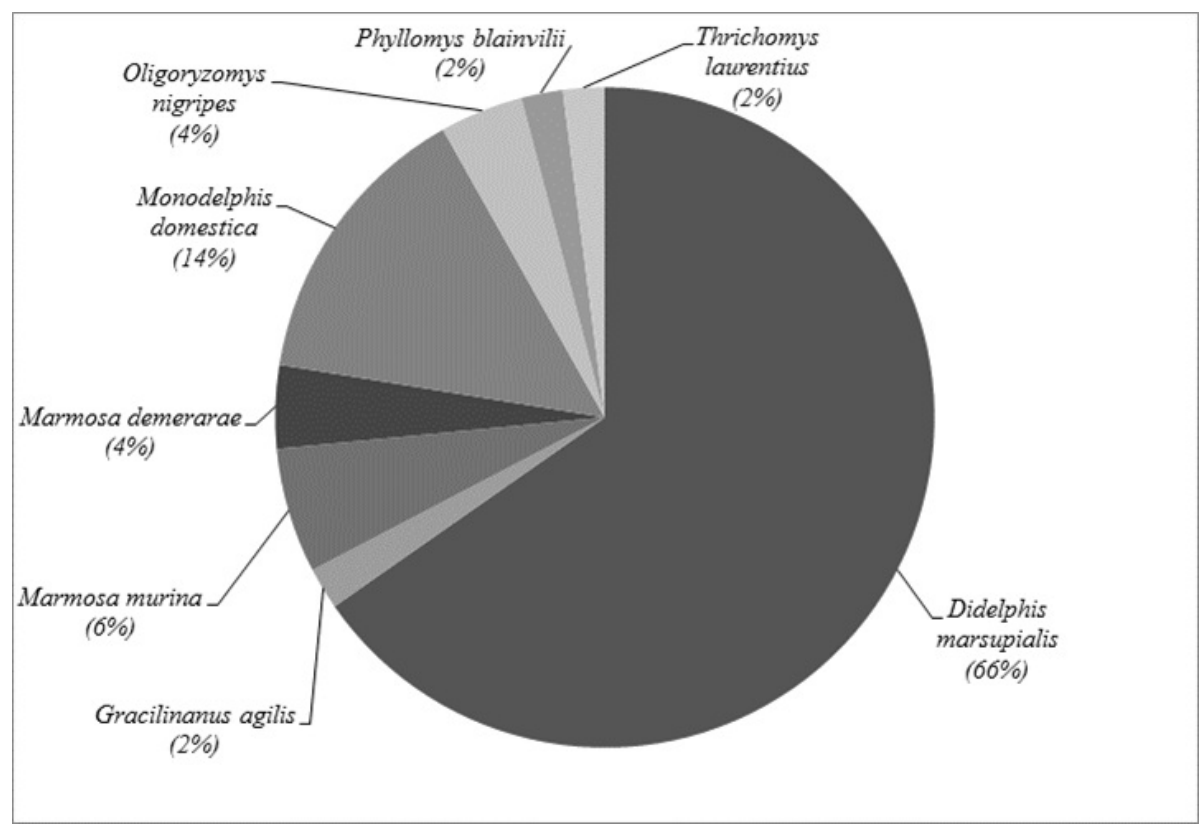

Figure 4. Pie-chart graphic illustrating the abundance of the small mammal species recorded in Mataraca, Paraíba. The absulute values were: Thrichomys laurentius, Phyllomys blainvilii and Gracilinanus agilis $(\mathrm{n}=1)$; Oligoryzomys nigripes and Marmosa dermerarae $(\mathrm{n}=2)$; Marmosa murina $(\mathrm{n}=3)$; Monodelphis domestica $(\mathrm{n}=7)$; Didelphis marsupialis $(\mathrm{n}=32)$.

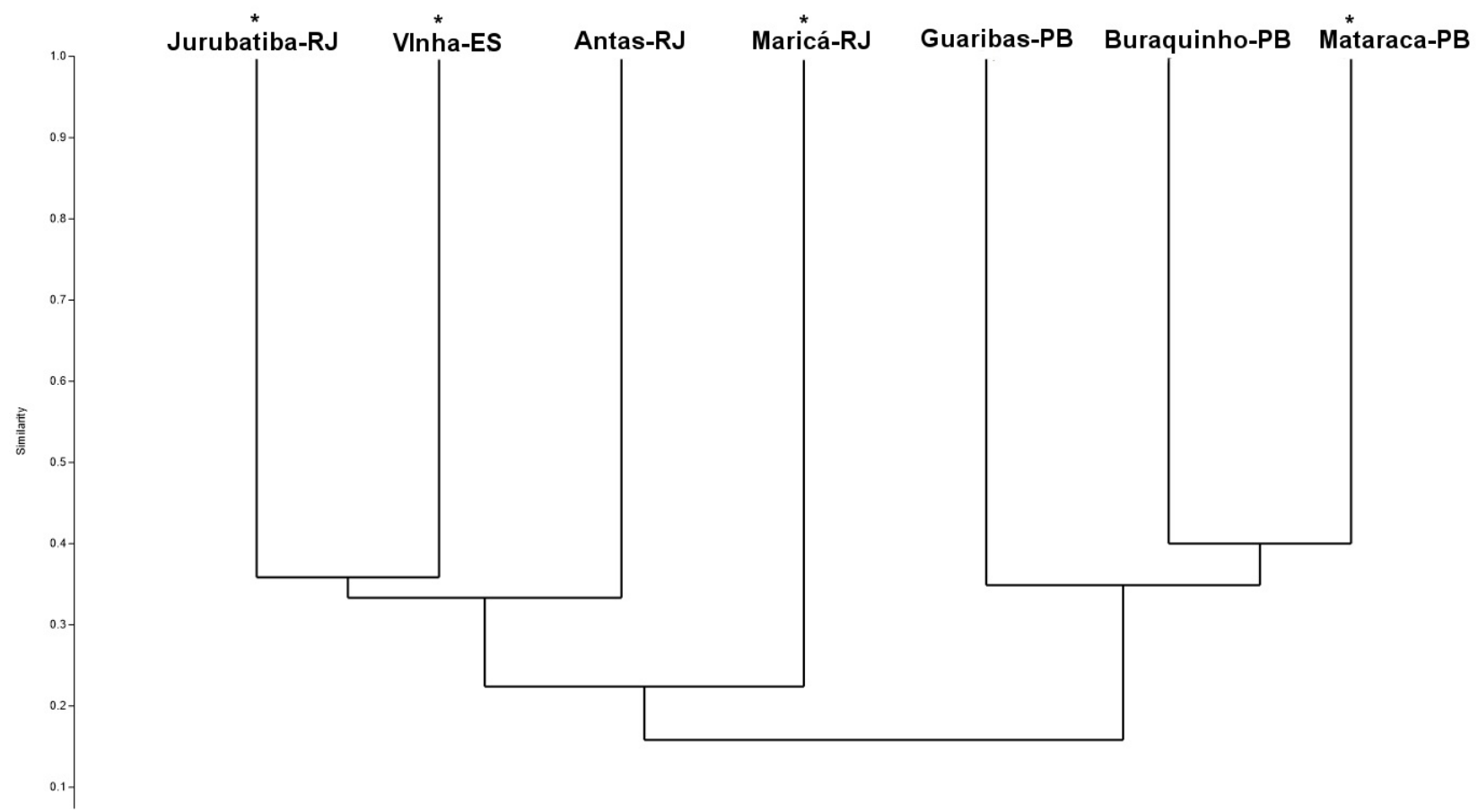

Figure 5. Similarity dendrogram between Atlantic Forest and Restinga localities for small, medium and large species of mammals. The asterisks identify areas of Restinga. The data was compiled according the works listed in Table 1. Acronyms of the areas as follow: Parque Nacional de Jurubatiba, Rio de Janeiro state (Jurubatiba-RJ); Reserva Biológica Poço das Antas, Rio de Janeiro state (Antas-RJ); Parque Estadual Paulo Cesar Vinhas, Espírito Santo state (Vinha-ES); Barra de Maricá, Rio de Janeiro state (Maricá-RJ); Reserva Biológica Guaribas, Paraíba state (Guaribas-PB); Refúgio de Vida Silvestre Mata do Buraquinho, Paraíba state (Buraquinho-PB). 


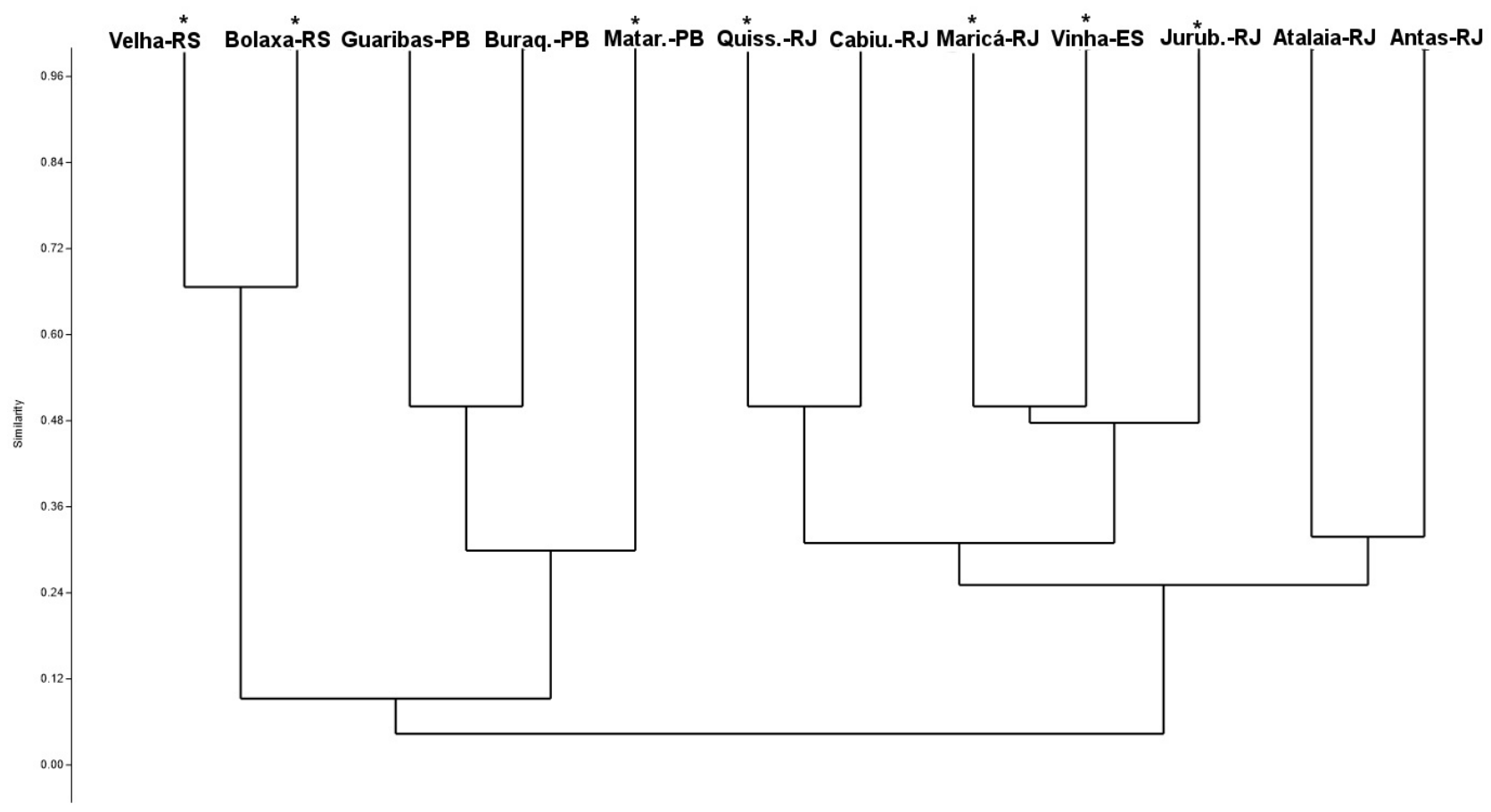

Figure 6. Similarity dendrogram between Atlantic Forest and Restinga localities for small non volant mammals. The asterisks identify areas of Restinga. The data was compiled according the works listed in Table 1. Acronyms of the areas as follows: Parque Nacional de Jurubatiba, Rio de Janeiro state (Jurub.-RJ); Reserva Biológica Poço das Antas, Rio de Janeiro state (Antas-RJ); Quissamã,, Rio de Janeiro state (Quiss.-RJ); Cabiunas,, Rio de Janeiro state (Cabiu.-RJ); Parque Natural Municipal de Atalaia,, Rio de Janeiro state (Atalaia-RJ); Parque Estadual Paulo Cesar Vinhas, Espírito Santo state (Vinhas-ES); Barra de Maricá,, Rio de Janeiro state (Maricá-RJ); Reserva Biológica Guaribas, Paraíba state (Guaribas-PB); Mata do Buraquinho, Paraíba state (Buraq.-PB); Estrada Velha, Rio Grande do Sul state (Velha-RS); Arroio Bolaxa, Rio Grande do Sul state (Bolaxa-RS).

\section{Discussion}

We recovered 30 species of mammals in Mataraca during 3 years of standardized sampling effort, interviews and sorting of museum specimens. Six species of marsupials, five xenarthrans, seven bats, three monkeys, five rodents and four carnivores compose the list, and half of them are medium and large mammals $(n=15)$. Apart from the three species of monkeys, which are typical from northeastern region (and eastern Amazon, in the case of Alouatta belzebul), all medium and large mammals are widespread throughout South America. Callithrix jacchus is also widespread, but it was originally from this region (Hershkovitz 1977). The same is valid for the species of bats sampled and for some species of rodents (Oligoryzomys nigripes and Coendou prehensilis are widespread in Brazil); the remaining species of rodents, Thrichomys laurentius, Phyllomys blainvilii and Dasyprocta iacki, are more restricted to northeastern region (Pêssoa et al. 2015, Campos \& Percequillo 2007, Feijó \& Langguth 2013, Leite \& Loss 2015).

The number of species surveyed on Mataraca is similar to the one observed in other areas of the northeastern portion of the Atlantic Forest. Percequillo et al. (2007) recorded 37 species for João Pessoa, Paraíba and Vieira (1953) registered 28 species in the state of Alagoas. In addition to the similarity in richness, these faunas are similar in terms of their composition, being mostly composed by elements of wide geographic distribution, generalists in habitat and dietary, and tolerant to environmental disturbances, as Didelphis marsupialis, Monodelphis domestica, Euphractus sexcinctus and Cerdocyon thous. Feijó et al. (2016) listed 70 species of mammals to the Reserva Biológica Guaribas, distant about $25 \mathrm{~km}$ from the Restinga of Mataraca which corresponds to the closest site with a long-term inventory. This great diversity reported by these authors can be explained by the nearly inventory (30 years) of mammals in this area. In addition, Reserva Biológica Guaribas shows different phytophysiognomies, which should favors this higher diversity compared to other areas of the Atlantic Forest. On the other hand, Mataraca presents species as Gracilinanus agilis, Rhynchonycteris naso and Phyllomys blainvilii that were not recovered from Reserva Biológica Guaribas. In comparison to other Restinga areas, where the richness of all mammals range from 18 species in Barra de Maricá, Rio de Janeiro (Cerqueira 1990, 2000) to 39 species in the Parque Estadual Paulo César Vinha, Espírito Santo (Moreira \& Mendes 2010), Mataraca stands out as one of the most diverse.

The six species of marsupials recorded in the Restinga of Mataraca represent $60 \%$ of the known diversity of this group for the Atlantic Forest on the northern bank of Rio São Francisco (Oliveira \& Langguth 2004, Bovendorp et al. 2017). This number also corresponds to $27 \%$ of marsupial species recorded for the Brazilian Atlantic Forest (Paglia et al. 2012). According to Oliveira \& Langguth (2004), the two species from Paraíba not sampled in this study are Thylamys karimii and Monodelphis americana, species usually uncommon in field surveys in this state. The first species exhibits a distribution throughout open formations (Carmignotto \& Monfort 2006), as the phytophysiognomies of Cerrado inserted in the Atlantic Forest of Paraíba (Thomas \& Barbosa 2008), and the second shows preference for more humid forests (Pardini et al. 2010). As well as Mataraca, Mata do Buraquinho (Percequillo et al. 2007) and Reserva Biológica Guaribas (Feijó et al. 2016) also count six species of marsupials. The composition differs regarding the presence of Gracilinanus agilis at Mataraca, Thylamys karimii at REBIO Guaribas and Monodelphis americana at Mata do Buraquinho.

Another noteworthy aspect of the mammalian fauna of Mataraca is the absence of rodents of the family Cricetidae, subfamily Sigmodontinae, with the exception of Oligoryzomys nigripes. This is the most diverse group of Neotropical mammals (Musser \& Carleton 2005, Patton et al. 
2015), being represented in the Atlantic Forest of Northeastern Brazil by 16 species (Bovendorp et al. 2017). In general, this group is representative in terms of diversity and abundance in communities of small mammals (e.g., Bergallo 1994, Vivo \& Gregorin 2000, Pardini 2004). A possible explanation for the absence of species of sigmodontine in Mataraca is the dominance in the area of the white-eared opossum, D. marsupialis, with $66 \%$ of abundance ( 32 specimens were trapped), (Figure 4). The great abundance of marsupials of the genus Didelphis has been associated with the decrease on the diversity of the small mammals' communities in areas of secondary forests (Fonseca \& Robinson 1990), as in Mataraca. In addition, Moura et al. (2008) suggest a greater sensitivity of rodents to drier environments, such as semideciduous forest, than marsupials. The sandy soil of Mataraca is very well drained and although a thick leaf litter is present, this stratum of the forest is quite dry (Figure 2 -D). Unlike other restinga areas from Southern Brazil (Cerqueira 2000, Quintela et al. 2012), we did not register the exotic murids Mus musculus and Rattus sp., which suggests that the area is free of invasive species that can present a deleterious effect on the community of small mammals. It is also noteworthy the presence of the echimyid rodent Phyllomys blainvilii. This record extended the distribution of the genus to the north (Campos \& Percequillo 2007). Recently, Loss \& Leite (2011) and Leite \& Loss (2015) pointed out that these specimens may represent a species not yet described, increasing the importance of future studies in the region.

Seven species of bats represent a small diversity compared to other nearby areas of the Atlantic Forest. Leal et al. (2013) registered nine species for the campus of the Universidade Federal de Pernambuco in the city of Recife. Percequillo et al. (2007) recorded 14 species for an urban fragment in João Pessoa, Paraíba. Silva \& Farias (2004) reported 15 species for an Ecological Station of Caetés, Pernambuco. This low diversity of bats obtained from the scientific collection may reflect occasional sampling rather than proper inventory in Mataraca. The material of UFPB assembled 48 specimens collected on April, May and September 2002. All bats registered in Mataraca are generalist omnivorous of the family Phyllostomidae and are well adapted to edge habitats and to moderately to well disturbed environments (see Gardner, 2008), with exception of the Emballonouridae Rhynchonycteris naso that has insectivorous habitat.

Regarding medium and large mammals, we recorded $51.8 \%$ of the 27 species present in the Atlantic Forest on the northern bank of Rio São Francisco (Feijó \& Langguth 2013). Nevertheless, it should be considered that the diversity recovered here could be underestimated, as in the case of felids. Some of the records from these taxa were obtained through footprints, precluding accurate species identification. Among the larger mammals it is also worth to mention the primates Cebus (Sapajus) flavius and Alouatta belzebul. During the three years of field work, several individuals of $C$. flavius were directly visualized in the region, suggesting a resident population of this threatened species in the area. C. flavius is critically endangered (de Oliveira et al. 2015) and occurs only in fragments of Atlantic Forest in the states of Alagoas, Paraíba, Pernambuco and Rio Grande do Norte (Oliveira \& Langguth 2006, Feijó \& Langguth 2013, Fialho et al. 2014). On the other hand, A. belzebul was observed only once during the study, which suggests that these animals frequent the area sporadically. Therefore, the preservation of the continuous areas of the Restinga forest of Mataraca is fundamental for the maintenance of these populations of primates.

Bradypus variegatus, Dasypus novemcinctus, Tamandua tetradactyla and Cyclopes didactylus were recorded only by interviews and no other considerations could be made about their conservation status. These species are widespread in the Atlantic Forest of northeastern Brazil (Feijó \& Langguth, 2013) and were recorded at REBIO Guaribas (Feijó et al.
2016), only $25 \mathrm{~km}$ from Mataraca. Thus, it is very likely that they occur at Mataraca, and we failed to sample them, due to our unstandardized sampling effort for medium-large mammals.

The analyzes of Jaccard show that the mammalian composition of Restingas are more similar to the nearby Atlantic Forest areas than with other Restinga areas (Figures 5 and 6). However, there are still few available contributions on the mammalian diversity of Restingas in Brazil, most of them concentrated in the southeastern region. The clustering of areas of northeastern Brazil with areas of Restingas of Rio Grande do Sul could be a consequence of the incompleteness of data available about Brazilian Restinga mammalian assemblages. Bovendorp et al (2017) listed 300 locations for the entire biome, but only three of them were conducted on the Restinga. Examining their faunal elements, we can only observe the sharing of white-ear-opossum (D. marsupialis) and the black-footed colilargo (O. nigripes) (supplementary material 1$)$. Possibly the other areas analyzed (from Rio de Janeiro and Espírito Santo) were much more similar among each other, causing the nesting of the remaining areas (Northeastern and Southern Brazil). Nevertheless, our results show that Restingas do not constitute an independent and autochthone faunal unit and support the hypothesis that Restinga areas present a mammalian assemblage similar to that found in adjacent Atlantic Forest areas (Cerqueira et al. 1990). Therefore, the preservation of the Restinga depends not only on actions focused on this coastal vegetation, but also requires a greater connectivity to nearby Atlantic Forest areas (Pardini et al. 2005).

\section{Acknowledgments}

To the mining company Lyondell Chemical Company for the logistics and financial support and for sponsoring the scientific initiation granted to BATPC and AF. We also want to thanks to Malva Hernández and Antonio Creão-Duarte for the invitation to join the project "Sucessão Ecológica e Regeneração de Restingas: Reflorestamento de Dunas em Mataraca, Paraíba" during whose development the present data was obtained. Thanks to Robson G. Santos, Gindomar G. Santana, Ana Cecília Falcão and the employees of the mining company for their efforts in the field. Also to Yuri Leite for the confirmation in the identification of the specimens UFPB 5690 and Alfredo Langguth for the aid in the preparation of a specimen UFPB 5368. Financial support was also granted by the National Research and Development Council (CNPq - Conselho Nacional de Pesquisa e Desenvolvimento, process number 477842/2004-6, granted to ARP) and from the Center of Exact and Natural Sciences of UFPB (Centro de Ciências Exatas e da Natureza, UFPB). We would also like to thank CAPES for granting the PNPD grant to BATPC and FAPEMA for financial support.

\section{Supplementary material}

The following online material is available for this article: Table S1

\section{Author's Contributions}

- BC - Substantial contribution in the concept and design of the study; Contribution to data collection; Contribution to data analysis and interpretation; Contribution to manuscript preparation.

- AF- Contribution to data collection; Contribution to data analysis and interpretation; Contribution to manuscript preparation

- PGB-Contribution to data collection; Contribution to critical revision, adding intellectual content

- ARP-Contribution to data collection; Contribution to critical revision, adding intellectual content. 


\section{Conflicts of interest}

The authors declares that they have no conflict of interest related to the publication of this manuscript

\section{References}

BERGALLO, H. G. 1994. Ecology of a small mammal community in an Atlantic Forest area in southeastern Brazil. Stud. Neotrop. Fauna E., 29(4): 197-217.

BOVENDORP, R., VILLAR, N., ABREU-JUNIOR, E. F., BELLO, C., REGOLIN, C., PERCEQUILLO, A. R., GALETTI, M. 2017. Atlantic small-mammal: a dataset of communities of rodents and marsupials of the Atlantic Forests of South America. Ecology, v. 0, n. 0, p. 0,

CAMPOS, B.A.T.P. \& PERCEQUILLO, A.R. 2007. Mammalia, Rodentia, Echimyidae, Phyllomys blainvilii (Jourdan, 1837): range extension and new geographic distribution map. Check List, 3(1): 18-20

CARMIGNOTTO, A. P., MONFORT, T. 2006. Taxonomy and distribution of the Brazilian species of Thylamys (Didelphimorphia : Didelphidae). Mammalia, 2006: 126-144.

CERQUEIRA, R., FERNANDEZ, F.A.S., QUINTELA, M. F. S. 1990. Mamíferos da restinga de Barra de Marica, Rio de Janeiro. Pap. Avulsos Zool., 37(9): 141-157.

CERQUEIRA, R. 2000. Ecologia funcional de mamíferos numa restinga do Estado do Rio de Janeiro. In Ecologia de Restingas e Lagoas Costeiras (Esteves, F. A. \& Lacerda, L. D. eds). NUPEM/UFRJ, Macaé, Rio de Janeiro, p. 189-212.

COLWELL R.K. 2013.EstimateS: Statistical estimation of species richness and shared species from samples. Version 9.Persistent $U R L<$ purl.oclc.org/estimates $>$.

CUNHA, L.O., FONTES, M.A.L., OLIVEIRA, A.D., E OLIVEIRA-FILHO, A.T. 2003. Análise multivariada da vegetação como ferramenta para avaliar a reabilitação de dunas litorâneas mineradas em Mataraca, Paraíba, Brasil. Rev. Árvore, 27(4): 503-515.

DE OLIVEIRA, M.M., BOUBLI, J.-P. \& KIERULFF, M.C.M. 2015. Sapajus flavius The IUCN Red List of Threatened Species, 2015:e.T136253A70612549.http:/ dx.doi.org/10.2305/IUCN.UK.2015.RLTS.T136253A70612549.en.Downloaded on08 May 2017.

DURÉ, R.C. 2013. Avaliação da restauração de dunas litorâneas numa área de mineração (Mataraca, Paraíba, Brasil). Monografia de conclusão de curso, Universidade Federal da Paraíba, João Pessoa. http://www.ccen.ufpb.br/cccb/ contents/monografias/2013.1/avaliacao-da-restauracao-florestal-de-dunaslitoraneas.pdf/view (last access in 14/09/2017).

EISENBERG, J. F. \& REDFORD, K. H. 1999. Mammals of the Neotropics: The central Neotropics. The University of Chicago Press, Chicago.

EMMONS, L. H. \& F. FEER 1997. Neotropical Rainforest Mammals, A Field Guide. $2^{\circ}$ Ed. The University of Chicago Press, Chicago.

FABIÁN, M. E., SOUZA, D. A. S., CARVALHO, F., LIMA, C. 2010. Mamíferos de áreas de restinga no Rio Grande do Sul. In Mamíferos de restinga e manguezais do Brasil (Pessôa, L. M., Tavares, W. C., Siciliano, S. Eds). Sociedade Brasileira de Mastozoologia Série Livros, 1, p. 209-224.

FEIJÓ, A., LANGGUTH, A. 2013. Mamíferos de médio e grande porte do nordeste do brasil: distribuição e taxonomia, com descrição de novas espécies. Rev. Nordest. Biol., 22(1/2): 3-225.

FEIJÓ, A., NUNES, H., LANGGUTH, A. 2016. Mamíferos da Reserva Biológica Guaribas, Paraíba, Brasil. Rev. Nordest. Biol.,24(1): 57-74,

FIALHO, M. S., VALENÇA-MONTENEGRO, M. M., SILVA, T. C. F., FERREIRA, J. G., LAROQUE, P. O. 2014. Ocorrência de Sapajus flavius e Alouatta belzebul no centro de endemismo de Pernambuco. Neotrop. Primates, 21:214-219.

FONSECA, G. A. B. \& ROBINSON, J. G. 1990. Forest size and structure: competitive and predatory effects on small mammal community structure. Biol. conserv., 53(4): 265-294.

FONSECA, G. A. B.; HERRMANN, G.; LEITE, Y. L. R.; MITTERMEIER, R. A.; RYLANDS, A. B.; PATTON, J. L. 1996. Lista Anotada dos Mamíferos do Brasil. Occasional Papers in Conservation Biology, n.4, p.1-38

GARDNER, A. L. 2008. Mammals of South America - VOL 1. Chicago \& London: The University of Chicago Press.

GURGEL-FILHO, N. M.; FEIJÓ, A.; LANGGUTH, A. 2015. Pequenos mamíferos do ceará (marsupiais, morcegos e roedores sigmodontineos) com discussão taxonômica de algumas espécies. Rev. Nordest. Biol., 23(2): 3-151.
HAMMER, O., HARPER, D. A. T., RYAN, P. D. 2009. PAST - Paleontological Statistics, ver. 1.89.

HERSHKOVITZ, P. 1977. Living new world monkeys (Platyrrhini), with an introduction to primates. University of Chicago Press, Chicago and London. Vol 1.

LEAL, E. S. B.; RAMALHO, D. F., MILLER, B. G.; FILHO, S. A. M.; ARAÚJO, V M. L.; SILVA, L. A. M. e GUERRA, D. Q. 2013 - Inventário da quiropterofauna (Mammalia: Chiroptera) do campus da Universidade Federal de Pernambuco, nordeste do Brasil. Bol. Mus. Biol. Mello Leitao, Nova Ser., 32: 53-70.

LEITE, Y. L. \& LOSS, A. C. 2015. Genus Phyllomys. In Mammals of South America (Patton, J. L., Pardiñas, U., D’Elía, G. eds). University of Chicago Press, Chicago, V. 2, p. 915-928

LINARES, O. J. 1998. Mamíferos de Venezuela. Sociedad Conservacionista Aldubon de Venezuela, Caracas.

LOSS, A. C. \& LEITE, Y. L. R. 2011. Evolutionary diversification of Phillomys (Rodentia: Echimyidae) in the Brazilian Forest, J. Mammal., 92(6): 1352-1366.

LUZ, J. L., COSTA, L. M., LOURENÇ, E. C., GOMES, L. A. C., ESBÉRARD, C. E. L. 2009. Bats from the Restinga das Neves, state of Espirito Santo, Southeastern Brazil. Check List, 5(2):364-369.

LUZ, J. L., MANGOLIN, R., ESBÉRARD, C. E. L., BERGALLO, H. G. 2011. Morcegos (Chiroptera) capturados em lagoas do Parque Nacional da Restinga de Jurubatiba, Rio de Janeiro, Brasil. Biota Neotrop. 11(4): 161-168.

MABESOONE, J. M. \& CASTRO, C. 1975. Desenvolvimento geomorfológico do Nordeste Brasileiro Bol. Nuc. Nord. Soc. Br. Geo, 3:5-35.

MOREIRA, D. O. \& MENDES, S. L. 2010. Diversidade de mamíferos em ecossistemas costeiros do estado do Espirito Santo. In Mamíferos de restinga e manguezais do Brasil (Pessôa, L. M., Tavares, W. C., Siciliano, S. Eds). Sociedade Brasileira de Mastozoologia Série Livros, 1, p. 59-74.

MOURA, M. C., GRELLE, C. E. V., BERGALLO, H. G. 2008. How does sampling protocol affect the richness and abundance of small mammals recorded in tropical forest? An example from the Atlantic Forest, Brazil. Neotrop. biol. conserv., 3: 51-58.

MUSSER, G.G. AND M.D. CARLETON. 2005. Superfamily Muroidea. In Mammal species of the world A taxonomic and geographic reference (Wilson, D. E. \& Reeder, D.A. Eds), The Johns Hopkins University Press, Baltimore, 3p.894-1531.

NOGUEIRA, M. R., MAZUREC, A. P., PERACHI, A. L. 2010. Morcegos em restingas: lista anotada e dados adicionais para o norte fluminense, sudeste do Brasil (Mammalia, Chiroptera). In Mamíferos de restinga e manguezais do Brasil (Pessôa, L. M., Tavares, W. C., Siciliano, S. Eds). Sociedade Brasileira de Mastozoologia Série Livros, 1, p. 75-93.

OLIVEIRA, F.F. \& LANGGUTH, A. 2004. Pequenos mamíferos (Didelphimorphia e Rodentia) de Paraíba e Pernambuco. Rev. Nordest. Biol., 18(2):19-85.

OLIVEIRA, M. M. e LANGGUTH, A. 2006 - Rediscovery of Marcgrave's capuchin monkey and designation of a neotype for Simia flavia Schreber, 1774 (Primates, Cebidae). Bol. Mus. Nac., Zool. 523: 1-16

OPREA, M., ESBÉRARD, C. E. L., VIEIRA, T. B., MENDES, P., PIMENTA, V. T., BRITO, D., DITCHFIELD, A. D. 2009. Bat community species richness and composition area in Southeastern Brazil. Braz. J. Biol., 69(4):1073-1079.

PAGLIA, A. P., FONSECA, G. A. B., RYLANDS, A. B., HERRMAN, G., AGUIAR, L. M. S., CHIARELLO, A. G., LEITE, Y. L., COSTA, L. P., SICILIANO, S., KIERULFF, M. C. M., MENDES, S. L., TAVARES, V. C., MITTERMEIER, R. A., PATTON, J. L. 2012. Lista anotada dos mamíferos do Brasil 2a Edição. Occasional Papers in Conservation Biology. 2a. Conservation International, Arligton.

PARDINI, R. 2004. Efects of forest fragmentation on small mammals in an Atlantic Forest landscape. Biodivers. Conserv., 13: 2567-2586.

PARDINI, R., SOUZA, S. M., BRAGA-NETO, R., METZGER J. P.2005. The role of forest structure, fragment size and corridors in maintaining small mammal abundance and diversity in an Atlantic forest landscape. Biol. Conserv., 124:253-266.

PATTON, J., PARDIÑAS, U. F. J., D'ELÍA, G. 2015. Mammals of South America - Rodents. The University of Chicago Press, Chicago, Vol. 2.

PERCEQUillo, A. R., SANTOS, K., CAMPOS, B. A. T. P., SANTOS, R., TOLEDO, G., LANGGUTH, A. 2007. Mamíferos de remanescentes florestais urbanos de João Pessoa, Paraíba. Biol. Geral Exp., 7(2): 17-31. 
PEREIRA, M.C.A., ARAÚJO, D.S.D. E PEREIRA, O.B. 2001. Estrutura de uma comunidade arbustiva da restinga de Barra de Maricá - RJ. Rev. Bras. Bot., 24 (3): 273-281.

PESSÔA, L. M., TAVARES, W. C., GONÇALVES, P. R. 2010. Mamíferos das restingas do macrocompartimento litorâneo da Bacia de Campos, Rio de Janeiro. In Mamíferos de restinga e manguezais do Brasil (Pessôa, L. M., Tavares, W. C., Siciliano, S. Eds). Sociedade Brasileira de Mastozoologia Série Livros, 1, p. 95-123.

QUINTELA, F. M., SANTOS, M. B., CHRISTOFF, A. U., GAVA, A. 2012. Pequenos Mamíferos não-voadores (Didelphiomorphia, Rodentia) em dois fragmentos de mata de restinga de Rio Grande, Planície Costeira do Rio Grande do Sul. Biota Neotrop. 12(1): 261-266.

ROCHA.C.F.D., BERGALLO, H.G., VAN SLUYS, M., ALVES, M.A.S., JAMEL, C.E., 2007. The remnants of restinga habitats in the brazilian Atlantic Forest of Rio de Janeiro state, Brazil: Habitat loss and risk of disappearance. Braz. J. Biol., 67(2):263-273.

SCARANO FR, DUARTE HM, RIBEIRO KT, RODRIGUES PJFP, BARCELLOS EMB, FRANCO AC, BRULFERT J, DELEÂENS E, LUÈ TTGE U. 2001. Four sites with contrasting environmental stress in southeastern Brazil: relations of species, life form diversity, and geographical distribution to ecophysiological parameters. Bot. J. Linn Soc., 136: 345-364.

SIKES, R. S. 2016. 2016 Guidelines of the American Society of Mammalogists for the use of wild mammals in research and education - Journal of Mammalogy 97: 663-688.
SILVA, L. A. M e FARIAS, A. M. I. 2004 - Quiropterofauna (Mammalia:Chiroptera) da Estação Ecológica de Caetés, Paulista, Pernambuco. Rev. Nordest. Biol. 18(1): 55-61.

THOMAS, W. W. \& BARBOSA, M. R. V. 2008. Natural vegetation types in the Atlantic Coastal Forest of Northeastern Brazil. In The Atlantic Coastal Forest of Northeastern Brazil (Thomas, W. W. eds). The New York Botanical Garden, New York.

VIEIRA, C. C. 1953. Sobre uma coleção de mamíferos do estado de Alagoas. Arq. Zool. Est. São Paulo, 8: 209-222.

VIVO, M. \& GREGORIN, R. 2001. Mamíferos. In Intervales (Leonel, C. ed.). Fundação para a Conservação e Produção Florestal do Estado de São Paulo, São Paulo.

VOSS, R. S., \& EMMONS, L. H. 1996. Mammalian Diversity in Neotropical Lowland Rainforests : a Preliminary Assessment. Bull. Am. Mus. Nat. Hist., 230:1-115.

ZAMITH, L.R. AND SCARANO, F.R. 2006. Restoration of a Restinga Sandy Coastal Plain in Brazil: Survival and Growth of Planted Woody Species. Restor. Ecol. 14(1): 87-94.

Received: 14/06/2017

Revised: 07/12/2017

Accepted: 01/09/2017

Published online: 01/02/2018 